\title{
Translation Between Creativity and Reproducing An Equivalent Original Text
}

\author{
Dr. Nabil Al-Awawdeh \\ Dept. of Modern Languages, University of Yarmouk, Irbid-Jordan \\ n.awawdeh@yu.edu.jo
}

\begin{abstract}
It isn't easy to find a comprehensive definition of translation; it is described as science, art and creativity at the same time. In this sense, literary translation, especially poetry, may be considered an art and creative work as opposed to scientific or political translation, where the words can be controlled according to the translator's linguistic skills and grammatical rules. The current research discusses how translation is an art and creative work. It is what many critics and scholars have reached for the "literary genre". It is also noted how the literal translation does not give the translated text its right, artistic colour, elevation, and influence in its original language unless it's based on translators' creativity. In this paper, our methodology is to look at literary translation as one of the most challenging types of translations, as it depends significantly on taste and the entry of the writer's imagination in the translation, whether he was a writer such as a poet, storyteller or novelist, and this in itself requires a creative spirit to be the image of translation and literary material creative artistic non-literal. Here the two-translator a writer or intellectual and professional translator differ. The latter depends on what he studied and read and what he researched in language study stages. Still, if he is also a writer or intellectual, many images and meanings will change. Yet, without prejudice to the essence of the translated text, and here even between a translator writer and another, the degree of creativity in translation varies and maybe at the same degree of different literary imagination. Finally, it is stressed that the essential in the art of translation is choosing the appropriate term so that it is easy, smooth, and light on the recipient here is a skill. The translator chooses the proper word for each material to be translated.
\end{abstract}

Keywords:

literary translation, creativity, profession, science or art

Article Received: 18 October 2020, Revised: 3 November 2020, Accepted: 24 December 2020

\section{Introduction:}

As translation studies try to realign the definition of translation vis-à-vis the original translated text, several factors play a significant role: the translator's subjectivity, questions of form, and the more prominent "social factors". This discussion addresses translators' creativity in appropriating and transferring the text as part of a more significant creative project. In this paper, translation is defined as creating a text out of a text. But in this text, the translator will respond to his literal and literary ability, knowledge of both languages, and the spirit of creativity, so he is free. Still, at the same time, this freedom is restricted by the original text, bypassing it to the creation of a parallel text requires a high level of creativity. Within such context, translation is also considered as a civilizational bridge between cultures, despite all criticisms that have been done around, especially in literary genres translations. Although some launched the famous maxim: translation is a betrayal of the original text, but in literature, translators encourage betrayal because our adherence to the original text's literal translation leads translation to lose its creative function. However, as for translating documents at all levels, the translator's honesty is necessary.

Concerning creativity, the translator's primary motivation is to love the text or the genre he chooses, so translation for him is an act of love, which helps the text to slide from its origin to its translator substitute. But when a translation is forced on the translator, the material benefit may replace love, especially in commercial translation. For example, those who translate legal or commercial documents move from contract to another focusing on delivering the job and getting their money without incorporating their creativity, 
if there is, in their translation. Nevertheless, translators must ensure creativity and honesty in their framework - the bearing of a rapid fabrication of such documents to easily benefit materially.

\section{Material and methods}

This paper uses a comparative method to discuss the term "translation", considering both theorists and professionals's views toward what is Translation: it mainly delves into whether the translation is an art, a science or a mixture of both. This research provides a brief discussion about whether the translator needs to have a scientific background for his profession or not such as translation theory. Also, it highlights if creativity is enough for translation. It also considers translation as a mixture and shows how some theorists consider translation differently from both linguistic and creative sides.

The discussion of theorists and professionals on what translation came out with many results which will be presented here. Among those results is that of theorists and professionals who have a tendency to consider both art and science as a combination for translation. The paper will conclude and stress that translation is represented in such combination in counting on the analysis method using examples from Franco-Arab translation. This method enables us to show that translation requires a wide range of skill, good knowledge of both languages' linguistic features, and a less knowledge of theories but also taste and creativity.

\section{Literature Review}

Scholars and translators look at the translation differently: some consider it an art as it depends on the translators' creativity through the skills he acquired in his life. On the other side, there are those who believe that it is a science with its subfields. It needs obtaining knowledge in both languages and essentials in theories. According to Bellos (1987), professionals are struggling "whether the translation is a trade, an art, a profession or a business" (164).

Belloc (1931) thinks that the status of the original text was never granted to translation and has been oppressed based on the basic assessment of letters (6). Therefore, According to Baker (2002) "the need for formal professional training in translation is necessary"(2). Castellano (1988), explains that the "profession is based on knowledge and experience. It has the most extended apprenticeship of any profession" (133). Toury (1982) notes that translation is cognitive science, and he refuses to keep only within linguistics.

Baker (2002) claims that translators argue against formal academic training in translation (3). Furthermore, Long (1996), thinks that the idea of turning translation intoa science is just a hope or dream, and has no applications in reality. The latter agrees with Bassnett (1980), who affirms that any argument about the translation as a science is outdated. Translation studies challenge the translation process and attempt to clarify the problem of equivalence and the components of meaning in a specific discipline (37). Savory (1969) confirms that translation is a kind of art. Moreover, Translation is not considered a science by Chukovskii(1984:93), who argues that translation should be seen as a high art.

As a new tendency, few scholars believe that translation is a mixture of both arts, as creativity is essential in translation and science.It needs skill, familiarity of the source and target language, and comprehension of theories of translation. Gabr (2001), presents translation as art and science. On the one hand, he states that translation is an art because it involves an ability that requires practice and preparation. On the other hand, translation is considered as science as it needs a deep foundation on language theories. Azizinezhad agrees with Gabr (2004) and asserts that translation shares many art and science features (2020].

This paper counts on all point of view of scholars and theorists and consider them highly, but we stand for creativity as the essential for literary 
translation, as it is in this paper interests, and does not ignore the need of scientific background that enriches translators knowledge, ability to chose and translate and also be familiar with everything encircle the act of translation.

\section{Discussion}

\subsection{Translation as a science or art}

In all disciplines, some questions are immortal and controversial. Perhaps the argumentative element that encapsulates such problems is the strength behind the enrichment of the human heritage with different theories and various approaches often contradictory. Whether the translation is a creative act or a literal transfer is one of these centuries-old dialectics where creativity was linked - sometimes directly or indirectly - with free translation and uncreativity with a literal translation, and each approach had its supporters who strive to highlight the advantages of this approach. And the disadvantages of the other method.

Supporters of literal translation blame the others of free translation for violating the integrity of the transmission of the original text, while supporters of free translation take on the advocates of literal translation blind obedience to the original text that necessarily leads from their point of view to the absence of creativity from the translation. The society's view throughout history of the translator's work had played an essential role in this field in periods when the translator's work was marginalized, literal translation was the most integral approach, and in periods that witnessed great respect for the translator's creative energies, free translation prevailed. Over time, the equation was not limited to open and literal translation, but other translation types entered the ladder, the closest to the literal and the closest to free. It is firmly believed that the answer to this question requires a precise definition of the concepts of creativity, honesty and fidelity. The translation is a real mixture of art that accompanies creativity and science that accompanies honesty and fidelity,(Nida. E.,1982 and Newmark, P. 1981).
Creativity is not associated with the extent of the translator's distance from the original text to the same degree that the balance of trust is not disturbed due to this distance. Creativity lies in the translator's ability to determine the goal behind his translation and his full knowledge of the recipient's quality of the translated text and the expectations of this recipient. Creativity also lies in the translator's ability of the conventions and norms of the language being transmitted from and the language sent to it. Conventions and Norms don't mean those related to vocabulary and grammar only, but the standards that rule the method of producing texts and necessarily lead to the existence of different types of texts in each language, so how a news report is drafted, for example, differs from that in which an advertisement, short story, poem, etc. is formulated, (Loffredo, E. \& Manuela, P., 2006).

When the translator can do all these matters without neglecting any of them in the two languages from which it is transmitted and transferred to it, he can determine the area within which he can move within its framework regarding the adoption of a free or literal translation and begin to transfer the text to the target language according to what is required by the customs of this language not the conventions and norms of the transmitted language therein lies both creativity and transportation honesty and fidelity. In general, it can be noted that literature in all its forms gives the translator a space to move towards a translation that is closer to free than that provided by other types of texts. It can also be notified that the more the text being transmitted from it is attached to the culture from which it was sent, the more it is necessary to move away from the literal translation, (Lefevere, A. (1992).

Thus, the translator who spends long nights translating a book with all that this matter requires intellectual and physical exhaustion; he wishes to obtain either the financial return that befits this hard work, or he hopes to spread his name as a professional translator. On the other side, a successful translator is a translator who is keen on selecting a book that he enjoys as a reader in the 
first place before becoming a translator for it. Nowadays, intellectuals are specializing in all practical and theoretical fields. The translator's interests should become a part of this universal tendency and adhere to the scientific world.

The translation of a scientific text (whether its subject belongs to the category of pure sciences or the variety of applied sciences) requires the translator, in addition to mastering the two languages, to be surrounded by the science to which the text belongs, and to have an in-depth knowledge of the content of terms in the source language and be able to choose the equivalent words in a language. Suppose the text belongs to the category of social and human sciences. In that case, the translation requires the conditions mentioned above, the right style, the durability of casting, the quality of the wording, and the selection of expressive vocabulary. For the meaning to be accurate and in harmony with the context smoothly, translation requires knowledge, training, accuracy and skill, (Olohan, M. 2016) .

Whereas if the text belongs to literary works, then translation becomes a form of creativity, as there are many components in the academic work that the translator must assimilate and assimilate and then weave them into the target language (the language to which he is translated) without any decrease or increase so that the new texture comes equivalent to maximum possible asset.
5. Analysis: The creativity of a translator- AlTahtawi

One of the prominent examples to show is in the "travelogue" of Rifa'a Al-Tahtawi "Takhlīṣ alIbrīz:" this book responds to a diversity of demands, targets a variety of audiences, and pursues several goals. This here directs the translator to choose particular texts that the society needs, and he wants to transfer. In this book, "Takhlīṣ al-Ibrīz," many chapters are focusing on the French constitution. Al-Tahtawi translated its chapters to show his developing society why the French are more developed in terms of rights and how laws govern them. Al-Tahtawi faced difficulties in translating many terms. These terms don't have equivalents in Arabic, or he did not want to use the existing equivalents because they are not appropriate in his culture. He tried to appropriate them to align with the Arabic and Muslim culture. It is notified that his translation has a religious and oriental essence.

The "Takhlīṣ al-Ibrīz" chapters are rich with examples talking about the French governance system, in particular, and articulates this complexity in a remarkable translation of the 1814 Charter. In this book, Al-Tahtawi shows his ability to navigate French, Arabic, and the content he translates. He resorts to lexicons intended to be familiar to his people to generate a perception of closeness to his describing governance system. The vocabulary that he used to translate such as:

\begin{tabular}{|l|l|l|l|l|l|}
\hline Arabic term & $\begin{array}{l}\text { English } \\
\text { meaning }\end{array}$ & Arabic term & $\begin{array}{l}\text { English } \\
\text { meaning }\end{array}$ & Arabic term & $\begin{array}{l}\text { English } \\
\text { meaning }\end{array}$ \\
\hline ḥaqq & The truth & istila' & $\begin{array}{l}\text { Taking in } \\
\text { possession }\end{array}$ & Qadi al-qudat & Chief judge \\
\hline sharī $a^{\prime} a$ & Islamic law & hukm & $\begin{array}{l}\text { Judgment or } \\
\text { decision }\end{array}$ & $\begin{array}{l}\text { Al-hakim al- } \\
\text { shari }\end{array}$ & $\begin{array}{l}\text { Islamic legal } \\
\text { governor }\end{array}$ \\
\hline
\end{tabular}




\begin{tabular}{|l|l|l|l|l|l|}
\hline Bayt al-māl & $\begin{array}{l}\text { Public } \\
\text { treasury }\end{array}$ & $\begin{array}{l}\text { Al-amr wa al- } \\
\text { nahi }\end{array}$ & $\begin{array}{l}\text { Commands } \\
\text { and } \\
\text { interdiction }\end{array}$ & al-mithl & $\begin{array}{l}\text { Make an } \\
\text { exemple }\end{array}$ \\
\hline Milla & $\begin{array}{l}\text { Creed or } \\
\text { religion }\end{array}$ & mu'amalat & Daily matters & mamnu' & prohabited \\
\hline haram & forbidden & mashura & $\begin{array}{l}\text { Islamic } \\
\text { consulation }\end{array}$ & & \\
\hline
\end{tabular}

And many other related terms to the translation. In a few cases, it can be said that it was the only vocabulary available (as in Milla for religious doctrine, hukm for jurisdiction, mamnū for prohibited, or mulghī for voided). Still, in most other cases Al-Tahtawi had other more readily available and conventional options, yet chose the idiomatic expressions that would sound familiar to a trained ear: Bayt al-māl instead of khazīna to refer to the treasury (art. 2), qāḍi al-quḍāt instead of muhradār or wazīr khātam al-malik to refer to the chancellor (art. 29), or quḍāt al-mu āmalāt instead of quḍāt al-tijāra to refer to judges with jurisdiction on commercial matters (art. 60).

Perhaps the clearest example in this area is the term that of 'law.' Al-Tahtawi calls 'sharī'a,' instead of calling it al-qānūn: 'qānūn.' (here the technical term qānūn, which already exists in Arabic, was avoided: even the translation for 'legal', was taken from shar '̄i a'. Al-Tahtawi use of sharī‘ a to refer to the French 'loi' must have sounded entirely inappropriate - yet familiar - to his people and traditional intellectuals; they used sharī'a to refer to the system of ethical and moral precepts connected to the Revelation, not the human-made qānūn or, even worse, a human-made non-Muslim foreign legal system. Al-Ṭahtawi intended to establish a connection between the familiar term 'sharī' a' and the foreign legal system, to appropriate this term and make it acceptable within his culture and he insistently and consistently does so.
The previous presentation highlighted a prominent, highly discussed topic: the definition of translation and how it is perceived among theorists and scholars. This prescription varies from one group to another whether to consider translation as an art. It is based on creativity or science because it needs knowledge, rules and education, or may both together because a creative translator needs to have the essentials and the basic understanding of translation.

This paper focused primarily on literary translation. It did show how the translator's creativity is essential because it is the only tool that enables him to manipulate the text and make it acceptable in the context for which it was translated. Al-Tatawi's work and his translation are proof of such creativity. Al-Tahtawi did not have any previous schooling in translation, and it is only the profession of translation that brought him to this high level of creativity in translation. As an outcome of this paper, it invites us to look further for similar works where creativity was enough to prove the capability of translation and where knowledge in translation can be acquired through practice.

\section{References}

[1] Al-Tahtawi, R. (1993). Takhlī ș al-Ibrīz, al-Qāhirah. al-Hay'ah al-M iṣrīyah al'Āmmah lil-Kitāb Azizinezhad, M. (2004). Is translation teachable? . Retrieved december 5, 2020

\section{Conclusion}


[2] Baker, M. (2002). In other words: A coursebook on translation . 9th ed. London: Routledge.

[3] Bassnett, S. (1980). Translation studies. London: Methuen and Co. Limited. Bates, E. S. (1943).

[4] Intertraffic: Studies in translation.

[5] Belloc, H. (1931). On translation . Oxford: Oxford University Press.

[6] Bellos, D. (1987). The business of translation and interpreting . London: Aslib.

[7] Castellano, L. (1988). Translators and interpreters mean business . London: Aslib.

[8] Chukovsky, K. (1984). The art of translation . London: Oxford University Press.

[9] Gabr, M. (2001). Programme evaluation: A missing critical link in translator training - Retrieved December 5, 2020 from http://accurapid.com/ journal/15training.htm

[10] Lefevere, A. (1992). Translating Literature: Practice and Theory in a Comparative Literature Context. New York: The Modern Language Association of America.

[11] Loffredo, Eugenia \& Manuela Perteghella and contributors (2006). Translation and Creativity: Perspectives on Creative Writing and Translation Studies. London/New York: Continuum.

[12] London: J. Cape. Bell, R. T. (1991). Translation and translating: Theory and practice. LondonNew York: Longman.

[13] Olohan, Maeve. 2016. Scientific and Technical Translation. London/New York: Routledge.

[14] Newmark, P. Approaches to Translation . Oxford: Pergamon, 1981.

[15] Nida Eugene A. Charles R Taber. The Theory and Practice of Translation. Leiden: E. J. Bill. 1982
[16] Savory, T. (1969). The art of translation . London: Jonathan Cape Ltd.

[17] Toury, G. (1982). Translation across cultures . New Delhi: Bahri Publications. 